\title{
Are oncogenes in a class of their own?
}

\section{Gordon Peters}

Oncogene Research. Editors-in-chief Claudio Basilico and Hidesaburo Hanafusa. Harwood. 4 issues per volume. UK £138, North America \$224, elsewhere $£ 170$ (corporate); UK £84, North America \$136, elsewhere £106 (library); UK £42, North America $\$ 70$, elsewhere $\$ 54$ (personal).

Oncogene. Editors Graham Currie, John Jenkins and Prem Reddy. Macmillan, London. 12/yr. UK $£ 190$, elsewhere $£ 210$.

At THE risk of sounding like Peter Duesberg, what exactly is an oncogene, and why are oncogenes so special as to warrant two new and exclusive journals? The believers would claim that oncogenes are special because they may have important roles in the development of cancer, or because studying them at least promises to add to our understanding of the processes involved. Given the rate at which information on these genes has been accruing, there has been a clear case for a forum in which the main advances might be brought rapidly and reputably to the

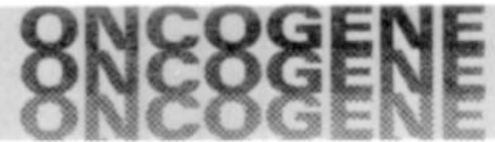

attention of the specialists, particularly as the 'scientific tabloids' can be rather fickle in what they regard as topical.

There is, however, the counter argument that to elevate oncogenes into a class of their own is misguided. Most of the genes that receive this accolade are really not that special, at least not in the way they are organized or expressed; and what a mixed bunch they are too - growth factors, receptors, protein kinases, DNAbinding proteins, transcription factors, and genes whose functions remain mysterious - all catapulted to fame and fortune by tumour viruses and cancer funding. In point of fact, many members of this apparent élite have more in common with ordinary, run-of-the-mill genes than they do with one another, and to issue them with a separate passport disguises this reality. Take the case of cellular oncogenes that belong to large families should there be a family passport, or should members who cannot prove their oncogenicity be excluded from these new journals?

Irrespective of the semantics, research on oncogenes remains fashionable and important, and workers in the field have met increasing difficulties in identifying the most appropriate and accommodating outlets for their results. The launch of Oncogene and Oncogene Research was therefore widely welcomed. But having two publications, and with such confusingly similar names, immediately creates a dilemma. Which will be regarded as the more prestigious? More seriously, can they both survive?
The editorial aspirations are virtually identical, both journals promising highquality, peer-reviewed papers, spiced with topical reviews (of which there have been rather few) and with relatively rapid publication times. In the volumes provided for appraisal, both can claim to have delivered, the standards being roughly on a par with Molecular and Cellular Biology or the $E M B O$ Journal, but judging from their thickness, neither appears to have been inundated with contributions. There is little to choose in the quality of papers that have appeared thus far, and nothing to choose in the calibre of the two international editorial boards; indeed some names appear on both boards.

At the level of principal editors, Oncogene Research might claim the edge, both in number and in international standing, but in marketing terms Oncogene wins hands down. Copies of Oncogene Research have been sporadic to say the least, while its competitor now boasts a regular monthly issue. The A4 format of Oncogene (maybe just a little too big), the high quality
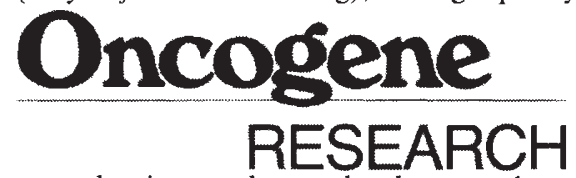

reproduction and a style that emulates both Cell and EMBO Journal make it very attractive, while, to my mind, the undoubted quality of Oncogene Research is offset by its rather old-fashioned air. I gather there are plans for a relaunch in new livery, but unless this is accompanied by a more reliable publication schedule, I see the balance tipping in favour of Oncogene.

If there is to be a circulation war between these two fledgling journals, then it will eventually be won or lost on the quality of papers each can attract. Locked in combat, they may be forced to compromise their standards while an uneasy truce would leave two slightly lame survivors. As neither will be the outlet of choice for the headline stories, and there may not be enough good copy to sustain them both, the scientific constituency these journals represent would be best served by a merger.

Gordon Peters is a Senior Scientist at the Imperial Cancer Research Fund Laboratories, St Bartholomew's Hospital, Dominion House, Bartholomew Close, London ECIA $7 B E, U K$.
NEW JOURNALS FROM PLENUM

\section{JOURNAL OF COMPUTER ASSISTED MICROSCOPY} Editor: John C. Russ

Deals with various aspects of the application of computer methods to acquire, process, and measure images. Topics inciude all kinds of microscopy and related instrumentation and novel instruments.

Subscription: Volume 1, 1989

(4 issues) $\$ 115.00 / \$ 135.00$ outside US

\section{JOURNAL OF \\ CLUSTER SCIENCE}

Co-Editors: David H. Russell and Boon K. Teo

An interdisciplinary forum for papers exploring the chemical and physical properties, bonding and structure, mathematics, and molecular biology of clusters.

Subscription: Volume 1, 1989 (4 issues) $\$ 115.00 / \$ 135.00$ outside US

\section{LABORATORY IMMUNOLOGY Official Journal of the Association of Medical Laboratory Immunologists Co-Editors: Herman Friedman and Mario R. Escobar}

Authoritative, refereed articles covering the newer methods for conducting specific immunologic tests, the clinical interpretations of such procedures, and the problems that arise in performing various immunologic assays.

Subscription: Volume 1, 1989 (2 issues)

Institutional rate: $\$ 50.00 / \$ 60.00$ outside US

Personal rate: $\$ 22.50 / \$ 27.00$ outside US

Write to the Sample Copy Dept. for a free examination copy of any Plenum journal!

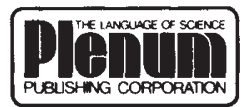

PLENUM PUBLISHING CORPORATION 233 Spring Street New York, NY 10013-1578

In the United Kingdom: 88/90 Middlesex Street London, E1 7EZ, England 